\title{
Gender and the ILC's 2019 Draft Articles on the Prevention and Punishment of Crimes Against Humanity
}

\author{
Indira Rosenthal \& Valerie Oosterveld
}

\begin{abstract}
The International Law Commission's Draft Articles on the Prevention and Punishment of Crimes Against Humanity document is the latest international instrument to address gender-based crimes under international law and the first to do so outside the context of international courts. The elaboration of a treaty on crimes against humanity provides a critical opportunity to affirm that gender-based crimes are among the gravest crimes under international law. This article examines discussions on the meaning of the term 'gender' under the ILC's Draft Articles, with reference to the discussions two decades prior on the definition of 'gender' in the Rome Statute of the International Criminal Court, the basis for the Articles' consideration of sexual and gender-based violence. It then turns to the ILC consultation process, and the 2019 discussion of the ILC's Draft Articles in the Sixth (Legal) Committee of the United Nations General Assembly on the term 'gender'. Additionally, it considers a number of concerns raised by States and civil society on the definition of some of the gender-based crimes included in the Draft Articles and concludes by arguing for a comprehensive gender analysis of all of the Draft Articles.
\end{abstract}

Keywords: gender, crimes against humanity, international criminal law, Rome Statute.

\section{Introduction}

It should be well accepted by now that any multilateral treaty adopted by the international community should be gender sensitive, particularly one focused on crimes against humanity. ${ }^{1}$ Therefore, it was expected that the International Law Commission (ILC) would consider gender-based violations when preparing its Draft Articles on the Prevention and Punishment of Crimes Against Humanity

* Indira Rosenthal, Independent Consultant, Gender, Law and Justice; PhD Candidate, Faculty of Law, University of Tasmania (Australia). Valerie Oosterveld, University of Western Ontario Faculty of Law (Canada).

1 There have been numerous advances in this respect in international criminal law jurisprudence. See, e.g., S. Brammertz \& M. Jarvis (Eds.), Prosecuting Conflict-Related Sexual Violence at the ICTY, Oxford, Oxford University Press, 2016. 
(Draft Articles). ${ }^{2}$ It was also encouraging that many States expressed views on gender issues in response to the ILC's call for submissions on its Draft Articles, particularly since this treaty would represent the first time that sexual and gender-based violence is criminalized in an international treaty outside of the context of international courts. It was particularly interesting to observe the evolution of the discussions around the term 'gender' in the Draft Articles, which reflected a microcosm of similar discussions in other negotiations, such as the drafting of the Rome Statute of the International Criminal Court (ICC), the Council of Europe's Convention on Preventing and Combating Violence Against Women and Domestic Violence (Istanbul Convention) and numerous other agreements. $^{3}$

This article begins by examining the negotiations on the definition of the term 'gender' in the Rome Statute of the ICC. It then turns to the definition of 'gender' in the ILC Draft Articles, the ILC's consultation process and the 2019 discussion of the ILC's Draft Articles in the Sixth (Legal) Committee of the United Nations (UN) General Assembly. It also considers other gender-related suggestions made by States and civil society with respect to the crimes against humanity of persecution, sexual violence and forced pregnancy. It ends by discussing whether a comprehensive review of gender-related implications is required of the Draft Articles as a whole.

\section{2 'Gender' in the Rome Statute of the ICC}

The term 'gender' was used and defined for the first time in international criminal law in the 1998 Rome Statute. ${ }^{4}$ For decades, this term has been a flashpoint within international multilateral negotiations, including in the Rome Statute negotiations. ${ }^{5}$ During those negotiations, two opposing views emerged. On one side of the debate were a minority of States and the Holy See, supported by conservative non-governmental organizations (NGOs), which equated 'gender' with the biological sex of males and females. They opposed the use of the term in the

2 Int'l Law Comm'n, 'Draft Articles on Prevention and Punishment of Crimes Against Humanity', in Int'l Law Comm'n, Report of on the Work of Its Seventy-First Session, UN Doc. A/74/10 (2019).

3 Rome Statute of the International Criminal Court, adopted by the UN Diplomatic Conference of Plenipotentiaries on 17 July 1998, entered into force on 1 July 2002, 2187 UNTS 3 [Rome Statute]; Council of Europe, Convention on Preventing and Combating Violence Against Women and Domestic Violence, adopted by the Council of Europe on 11 May 2011, entered into force on 1 August 2014, CETS 210 [Istanbul Convention]. See also, e.g., Report of the Fourth World Conference on Women, adopted at the 16th plenary meeting by United Nations on 15 September 1995, Addendum, Ann. IV, UN Doc. A/CONF.177/20/Rev.1, UN Sales No. 96.IV.13 (1996); Report of the United Nations Conference on Human Settlements (Habitat II), adopted at the 18th plenary meeting by UN Conference on Human Settlements on 14 June 1996, Ann. 1, UN Doc. A/CONF.165/14 (1996), Para. 46.

4 The term is defined in the Rome Statute, Art. 7(3), and also appears in Arts. 7(1)(h), 21(3), 42(9), 54 , and 68.

5 See, e.g., V. Oosterveld, "The Definition of "Gender" in the Rome Statute of the International Criminal Court: A Step Forward or Back for International Criminal Justice?' Harvard Human Rights Journal, Vol. 18, 2005, pp. 55-84, at 66-67 and notes 62-63. 
Rome Statute, as they associated it "with ideas they [view] as transgressive, such as women's empowerment, equality between the sexes, and the end of discrimination against people who are lesbian, gay, bisexual, transgender, intersex, or queer (LGBTIQ)". ${ }^{6}$ However, once it became clear that they could not prevent its use, they sought to give it a narrow, biologically-focused definition. ${ }^{7}$ On the other side of the debate were the majority of States and NGOs, which understood 'gender' to refer to socially-constructed 'maleness' and 'femaleness'; in other words, a learnt rather than innate category. ${ }^{8}$ They understood 'gender' to include sociallydetermined roles, opportunities and expectations (including with respect to physical appearance and behaviour) attributed to a person on the basis of their actual or perceived biological sex. ${ }^{9}$ This was how the term had been understood in the UN system prior to the Rome Statute negotiations. ${ }^{10}$

After tense and prolonged negotiations, a solution was finally adopted, defining the term in Article 7(3) of the Rome Statute, which states:

For the purpose of this Statute, it is understood that the term "gender" refers to the two sexes, male and female, within the context of society. The term "gender" does not indicate any meaning different from the above. ${ }^{11}$

This definition has been described as "constructively ambiguous" - a term (and tactic) sometimes used by diplomats during treaty negotiations to accommodate seemingly irreconcilable views. ${ }^{12}$ In this case, the impasse in the negotiations was resolved by referring in the definition to both the social construction of maleness and femaleness ("within the context of society") and the biological aspects of this social construction ("the two sexes"). As such, it provides a broad definition that covers all manifestations of socially-constructed gender norms, and is flexible enough to embrace future developments in international law.

This outcome is reflected in the ICC Prosecutor's Policy Paper on Sexual and Gender-based Crimes. It states that the Rome Statute definition "acknowledge[es] the social construction of gender, and the accompanying roles, behaviours, activi-

6 R. Grey, J. O’Donohue, I. Rosenthal, et al., 'Gender-Based Persecution as a Crime Against Humanity, The Road Ahead’, Journal of International Criminal Justice, Vol. 17, 2019, pp. 957-979, at 958.

7 Oosterveld, 2005, supra note 5, pp. 64-65.

8 Ibid.

9 This was reflected in the two main UN definitions in use at the time of the adoption of the Rome Statute: Oosterveld, 2005, supra note 5, p. 67. These definitions were from 'Report of the Expert Group Meeting on the Development of Guidelines for the Integration of Gender Perspectives in United Nations Human Rights Activities and Programs', UN Doc. E/CN.4/1996/105 (1995), at Para. 13; and 'Integrating the Human Rights of Women Throughout the United Nations System: Report of the Secretary-General', UN Doc. E/CN.4/1997/40 (1996), at Para. 10.

10 Oosterveld, 2005, supra note 5, p. 67.

11 Art. 7 lists the crimes against humanity over which the ICC has jurisdiction, including persecution on a number of specified grounds that include 'gender' (Art. 7(1)(h)). 'Gender' is the only persecutory ground defined in the Rome Statute.

12 V. Oosterveld, 'Constructive Ambiguity and the Meaning of "Gender" for the International Criminal Court', International Feminist Journal of Politics, Vol. 16, No. 4, 2014, pp. 563-580, at 564. 
ties, and attributes assigned to women and men, and to girls and boys". ${ }^{13}$ The ICC's judges have yet to discuss the definition in their jurisprudence, but may do so in the trial of Prosecutor $v$. Al Hassan, the first-ever case involving charges of the crime against humanity of gender-based persecution. ${ }^{14}$

Despite the resolution in Rome, the definition has been criticized precisely for its ambiguity over the intervening twenty-two years, ${ }^{15}$ and has not been replicated in the statutes of subsequent international criminal tribunals. ${ }^{16}$ Moreover, the conflict over its use at the international level has continued. In fact, the same States and NGOs that opposed a definition of 'gender' as a social construct during the ICC negotiations continue to try to block its application, whenever possible, in the UN system and other multilateral fora. ${ }^{17}$ It is for this reason that, when the idea of a crimes against humanity treaty was first proposed by civil society, experts suggested that the term 'gender' be left undefined or, if a definition was to be included, a clearer iteration that "more obviously satisfies the principle of legality" be used. ${ }^{18}$

\section{Defining 'Gender' in the ILC Draft}

It was against this background that the ILC began considering the issue of a draft treaty on crimes against humanity in $2014 .{ }^{19}$ An ILC-appointed Special Rapporteur, Sean Murphy, led this work, reporting back several times to the ILC with a series of proposals for the Draft Articles that it ultimately adopted. These included a proposal to replicate the Rome Statute's list of crimes against humanity violations, including its definition of the term 'gender', which delineates the

13 Office of the Prosecutor of the International Criminal Court, 'Policy Paper on Sexual and GenderBased Crimes', 2014, p. 3.

14 Public Redacted Version of "Submission of Prosecution Trial Brief", Prosecutor v. Al Hassan Ag Abdoul Aziz Ag Mohamed Ag Mahmoud, ICC-01/12-01/18, 18 May 2020, pp. 6-9. The Al Hassan trial began on 13 July 2020.

15 See Oosterveld, 2005, supra note 5, pp. 55-56, describing negative reactions, and p. 77 for positive reactions.

16 The definition was used, however, in the East Timor panels: United Nations Transitional Administration in East Timor, Reg. 2000/15 on the Establishment of Panels with Exclusive Jurisdiction over Serious Criminal Offences, Section 5.3, UN Doc. UNTAET/REG/2000/15 (2005).

17 See, e.g., D. Otto, 'Holding up Half the Sky, but for Whose Benefit?: A Critical Analysis of the Fourth World Conference on Women', Australian Feminist Law Journal, Vol. 6, No. 1, 1996, pp. 7-28; J. Borger, 'Trump Administration Wants to Remove 'Gender' from UN Human Rights Documents', The Guardian, 25 October 2018, available at: www.theguardian.com/world/2018/ oct/24/trump-administration-gender-transgender-united-nations; Amnesty International, 'Hungary: Blocking of Domestic Violence Treaty Further Exposes Women During COVID-19 Crisis', 5 May 2020, available at: www.amnesty.org/en/latest/news/2020/05/hungary-blocking-ofdomestic-violence-treaty-further-exposes-women/, on the Hungarian government's incorrect claims that the Istanbul Convention "prescribes dangerous gender ideologies".

18 See, e.g., V. Oosterveld, 'Gender-Based Crimes Against Humanity', in L.N. Sadat (Ed.), Forging a Convention for Crimes Against Humanity, New York, Cambridge University Press, 2011, pp. 81-83.

19 Int'l Law Comm'n, Report on the Work of Its Sixty-Sixth Session, UN Doc. A/69/10 (2014), Para. 266. 
crime against humanity of persecution on gender grounds. ${ }^{20}$ The ILC justified this approach on the basis that the "Rome Statute definition [of crimes against humanity] represents a widely-accepted definition of settled international law", concluding that "[a]s such, for the present draft articles, it should be used verbatim". ${ }^{21}$

During the early part of the ILC's deliberations on the Draft Articles, some supportive States engaged in the process urged the ILC to avoid reopening the fierce debate on the meaning and use of the term 'gender' by incorporating the Rome Statute definition in its entirety. ${ }^{22}$ They feared that the 'gender' definition debate was so polarizing that departing from the Rome Statute approach could derail the crimes against humanity treaty project. However, by the time the ILC submitted its second reading of the Draft Articles to the UN General Assembly four years later, it had reversed its position and dropped the definition of 'gender' altogether. ${ }^{23}$

What prompted this change of approach? In the intervening years, a number of States, UN bodies and NGOs from around the world had provided comments and observations on the Draft Articles at the ILC's invitation. Their responses to the first review of the text on this issue revealed a significant level of concern with, and even opposition to, adopting the Rome Statute's definition of 'gender'. Ultimately, the ILC found this feedback persuasive. ${ }^{24}$

The reasonably high level of engagement on this issue by both governments and NGOs did not arise organically. Rather, it was prompted by a civil society campaign directed by a consortium with the express purpose of mobilizing against the replication of the Rome Statute 'gender' definition, and certain other gender-related provisions, in the Draft Articles. The stated objective of the NGOs was to ensure that a future crimes against humanity treaty delivered "better protection to women and LGBTIQ persons". ${ }^{25}$

20 S. Murphy (Special Rapporteur on Crimes Against Humanity), First Report on Crimes Against Humanity, UN Doc. A/CN.4/680 (2015), at p. 87. Note that the definition was adopted by the ILC verbatim from the Rome Statute, with three exceptions related to the jurisdiction of the ICC and therefore not relevant to the draft convention.

21 Ibid., Para. 267.

22 C.C. Jalloh, 'The International Law Commission's First Draft Convention on Crimes Against Humanity: Codification, Progressive Development, or Both?', Case Western Reserve Journal of International Law, Vol. 52, No. 1, 2020, pp. 331-405, at 358.

23 Int'l Law Comm'n, Report of the ILC on the Work of Its Seventy-First Session, UN Doc. A/74/10 (2019), Para. 42.

24 Ibid., Paras. 41-42; S. Murphy, (Special Rapporteur on Crimes Against Humanity), Fourth Report on Crimes Against Humanity, UN Doc. A/CN.4/725 (2019), Paras. 80-86. Note that the ILC Statute requires it to take into account the views of States.

25 The consortium comprised MADRE, OutRight Action International, The Human Rights and Gender Justice (HRGJ) Clinic of the City of New York (CUNY) School of Law, and the Center for Socio-Legal Research at the Universidad de Los Andes, available at: www.madre.org/ genderingCAH. 


\section{The ILC Consultation Process}

The ILC invited comments on its first draft of the text, which, in this case, was completed in 2017, and subsequently received responses from thirty-nine States to its request for views on the Draft Articles. ${ }^{26}$ The primary concern among responding States about the Rome Statute's 'gender' definition was:

[It] does not take into consideration the developments of the last twenty years in the areas of international human rights law and international criminal law, particularly with regard to sexual and gender-based crimes[.] ${ }^{27}$

As well, they were concerned that the definition is "opaque, outdated and not in line with the recent, more inclusive and gender-sensitive definitions of 'gender"; 28 is "obsolete" 29 and "does not reflect current realities and content of international law". ${ }^{30}$ These same concerns were repeated in different formulae by nineteen of the thirty-eight countries that submitted written comments on the Draft Articles, echoing the views advocated by the civil society campaigners, as discussed later in this article. ${ }^{31}$

The ILC's Special Rapporteur reported that States advancing these views identified key developments in international law since the adoption of the Rome Statute to support their positions. These included the adoption by the ICC Prosecutor in 2014 of the public Policy Paper on Sexual and Gender-based Crimes and its understanding of gender; ${ }^{32}$ guidance from the International Committee of the Red Cross in 2004 on Addressing the Needs of Women Affected by Armed Conflict; ${ }^{33}$ the Convention on the Elimination of All Forms of Discrimination Against

26 Argentina, Australia, Austria, Belarus, Belgium, Bosnia and Herzegovina, Brazil, Canada, Chile, Costa Rica, Cuba, the Czech Republic, El Salvador, Estonia, France, Germany, Greece, Israel, Japan, Liechtenstein, Malta, Morocco, the Netherlands, New Zealand, Panama, Peru, Portugal, Sierra Leone, Singapore, Sweden (on behalf of the five Nordic countries: Denmark, Finland, Iceland, Norway and Sweden), Switzerland, Ukraine, the United Kingdom of Great Britain and Northern Ireland, the United States of America and Uruguay. Int'l Law Comm'n, Comments and Observations Received from Governments, International Organizations and Others, UN Doc. A/CN. 4/726+Add.1+Add.2 (2019).

27 Murphy, supra note 24, Comments and observations of Belgium, Para. 80.

28 Ibid., Comments and observations of Bosnia and Herzegovina, Para. 80.

29 Ibid., Comments and observations of Costa Rica, Para. 80.

30 Ibid., Comments and observations of Sweden on behalf of the Nordic countries, as reported in Murphy, Para. 80.

31 The 19 States were Argentina, Belgium, Brazil, Bosnia and Herzegovina, Canada, Chile, Costa Rica, El Salvador, Estonia, Liechtenstein, Malta, New Zealand, Sweden (on behalf of the Nordic countries), the United Kingdom and Uruguay. Ibid., p. 32, note 181.

32 The Policy pledges the ICC Office of the Prosecutor to "apply and interpret the Rome Statute definition of gender in accordance with internationally recognised human rights" as required under Art. 21(3) of the Statute: ICC Office of the Prosecutor, Policy Paper, 2014, Para. 15. For a discussion of the Policy Paper, see, e.g., V. Oosterveld, 'The ICC Policy Paper on Sexual and GenderBased Crimes: A Crucial Step for International Criminal Law', William and Mary Journal of Women and the Law, Vol. 24, No. 3, 2018, pp. 443-457.

33 International Committee of the Red Cross, 'Addressing the Needs of Women Affected by Armed Conflict: an ICRC Guidance Document', Geneva, ICRC, 2004, p. 7. 
Women Committee's 2010 General Recommendation No. 28 on States Parties' Core Treaty Obligations under Article 2;34 adoption by the Council of Europe of the 2011 Istanbul Convention; ${ }^{35}$ and recent reports of UN Special Rapporteurs and independent experts. ${ }^{36}$ Each of these authoritative documents share a common understanding of 'gender' as a social construct, which they set out explicitly.

Sixteen of the nineteen States commenting on the definition of 'gender' recommended that it be deleted. The remaining three (Chile, Costa Rica and Liechtenstein) proposed replacing it with a clearer definition, but if there was no agreement on this, that it should be deleted. ${ }^{37}$

The UN Office of the High Commissioner for Human Rights, ${ }^{38}$ twenty-four UN Special Rapporteurs and an independent adviser urged the Commission "to either remove the definition of gender in article 3(3) ... (since no other persecutory category comes with a definition) or to insist on the social construction of gender as it is widely recognized to be". ${ }^{39}$

In addition, 583 civil society organizations from 103 countries, as well as many academics, signed an open letter drafted by the civil society consortium recommending that the definition of 'gender' either be removed or revised using the definition of gender set out by the Office of the Prosecutor in the Policy Paper. ${ }^{40}$ Several separate submissions were also made by NGOs and some academic experts along similar lines. ${ }^{41}$ For example, the consortium made a separate submission in which it cited jurisprudence from the ad hoc tribunals for the former Yugoslavia and Rwanda as evidence of an evolving understanding of 'gender', and seventy African-based civil society organizations and human rights activists argued for an inclusive understanding of gender in the treaty as it concerns the most serious atrocities and so, "by its nature should protect all of us". ${ }^{2}$

In the end, in light of the concerns raised, and in the absence of a provision like Article 21(3) of the Rome Statute requiring the articles to be interpreted consistently with international human rights law and without any adverse distinc-

34 Committee on the Elimination of Discrimination Against Women, General Recommendation No. 28 on the Core Obligations of States Parties under Article 2 of the Convention (CEDAW/C/GC/ 28). Para. 5 of the Recommendation notes that, "[a]lthough CEDAW only refers to sex-based discrimination, interpreting article 1 together with articles 2 (f) and 5 (a) indicates that the Convention covers gender-based discrimination against women." It explains the difference in meaning between the term 'sex' (biological differences) and 'gender' (socially constructed identities, attributes and roles). Note, Art. 2 obliges States Parties to condemn discrimination against women and "to pursue all available means" and a policy to eliminate it. Istanbul Convention, supra note 3.

For a list, see Murphy, supra note 24, p. 33, fn. 192.

Ibid., Para. 82.

Ibid., Para. 83.

Ibid., Para. 83.

Ibid., Para. 84. See also L. Davis, 'This Is How We Won a Historic Victory for Women's and LGBTIQ Rights in International Law', Press Release, 25 June 2019, available at: www.madre.org/ press-publications/article/how-we-won-historic-victory-women's-and-lgbtiq-rights-international -la. The NGO open letter is available at: www.madre.org/press-publications/human-rightsreport/sign-now-support-gender-rights-crimes-against-humanity-treaty.

For a list, see Murphy, supra note 24, p. 35, fn. 201.

Ibid., Para. 84. 
tion on grounds such as gender, ${ }^{43}$ the Special Rapporteur recommended that the ILC delete the definition from the Draft Articles. ${ }^{44}$ The ILC concurred and the definition was removed.

\section{Debate on the Draft Articles - 2019 UN General Assembly Sixth Committee}

The ILC submitted its second reading of the Draft Articles to the UN General Assembly for consideration at its seventy-fourth session in 2019. ${ }^{45}$ In all, fifty governments, as well as Sierra Leone on behalf of the Africa Group and Norway on behalf of the Nordic Group, made statements on the Draft Articles. ${ }^{46}$ Of these, seventeen States and the Holy See specifically addressed the removal of the definition of 'gender'. Five States and the Holy See argued against the removal of the definition, ${ }^{47}$ and twelve spoke in support. ${ }^{48}$ The statements made by these two groups, although not detailed or comprehensive, confirm that the strongly held opposing viewpoints on the meaning of 'gender' that led to the "constructively ambiguous" 49 solution to the definition in the Rome Statute have not dissipated.

The group arguing for the retention of the Rome Statute definition wished to limit the meaning of 'gender' to that of male or female biological sex. Of this group, two States - Senegal and Sudan - said that its deletion would impact on whether a crimes against humanity treaty could be elaborated at all. ${ }^{50}$ For example, Senegal said it was concerned with the removal of the definition and stated that this "will undoubtedly remain one of the major obstacles to the elaboration of the convention". ${ }^{51}$ Others who regretted the ILC's decision not to include the Rome Statute definition of 'gender' referred to the sensitivity of the issue as a reason it should have been retained. In their view, the definition represents "internationally agreed language" 52 that the ILC should adopt "to ensure the

43 The combination of Arts. 7(3) and 21(3) of the Rome Statute ensures that the 'gender' definition evolves as international human rights and non-discrimination laws evolve.

44 Murphy, supra note 24, Paras. 86, 101-103.

45 Ibid., Para. 44.

46 Non-State observers, the Council of Europe, European Union and the Holy See also made statements, available at: www.un.org/en/ga/sixth/74/ilc.shtml.

47 They were Belarus, Egypt, Senegal, Sudan, Togo, Uzbekistan and the Holy See: Sixth Committee, 'Summary Record of the 26th Meeting', 29 October 2019, UN Doc. A/C.6/74/SR.24.

48 They were Argentina, Belgium, Canada, Estonia, New Zealand, Norway (on behalf of the Nordic Group - Denmark, Finland, Iceland, Norway and Sweden), Slovenia and the United Kingdom. See Whitney R. Harris World Law Institute, 'Compilation of Government Reactions to the International Law Commission's Project on Crimes Against Humanity', July 2020, available at: https://law.wustl.edu/wp-content/uploads/2020/08/Compilation-of-6th-Committee-Responsesto-CAH-2013-2019.pdf.

49 Oosterveld, supra note 12.

50 Whitney R. Harris World Law Institute, supra note 48, pp. 52, 54.

51 It stated: "restera, sans doute, l'un des obstacles majeurs á l'élaboration de la convention." 'Projet de Déclaration de la délégation Sénégalaise', 28 October 2019, available at: http:// statements.unmeetings.org/media2/23328751/-f-senegal-statement.pdf.

52 See, e.g., statement by Uzbekistan, Sixth Committee, 'Summary Record of the 26th Meeting', 31 October 2019, UN Doc. A/C.6/74/SR.26, Para. 32. 
universality of a future convention" ${ }^{53}$ Others argued that the Rome Statute language is also reflected in domestic laws: Togo reported that its national law defined 'gender' as referring to the "two sexes, male and female, pursuant to the Togolese Persons and Family Code, which did not indicate any other meaning". ${ }^{4}$

On the other hand, twelve countries supported the removal of the definition, with some indicating a second alternative of clearly defining 'gender' as a social construct. ${ }^{55}$ Of these, a number of countries explicitly stated that they were "pleased" that the ILC had removed the 'gender' definition. ${ }^{56}$ They considered it to be out of step with the international community's contemporary understanding of gender, which they said has evolved since 1998.

On the basis of the brief statements made in the Sixth Committee, it seems likely that the contention around the use and meaning of the term 'gender' will continue in any future negotiations on a crime against humanity treaty. At the same time, the ILC's consultation process and the Sixth Committee debate reveal a much deeper and more widespread understanding of the term 'gender' than was evident in 1998 at the adoption of the Rome Statute. This reflects a shift among at least some in the international community in understanding the ways in which gender norms are used to discriminate against and persecute people who are, or who are perceived to be, gender nonconforming. ${ }^{57}$ However, it should be noted that this understanding is not entirely new. At the Rome Statute negotiations, many States were aware of the history of persecution of homosexual men by the Nazis during the Second World War, as well as the continuing discrimination and vilification of LGBTIQ people in many countries around the world. Ensuring that the Rome Statute had jurisdiction over all kinds of gender-based persecution, including persecution on grounds of sexual orientation and gender identity, was therefore important for a large number of States negotiating the Rome Statute.

\section{Beyond the Definition of 'Gender': Other Gender-related Concerns}

Whether or not to include a definition of 'gender' was not the only gender-related issue arising in relation to the Draft Articles. Several States, UN Special Rapporteurs, civil society organizations and others raised concerns about other gender-

53 See, e.g., statement by Belarus, Sixth Committee, 'Summary Record of the 24th Meeting', 31 October 2019, UN Doc. A/C.6/74/SR.24, Para. 75.

54 Statement by Togo, Sixth Committee, 'Summary Record of the 26th Meeting', 31 October 2019, UN Doc. A/C.6/74/SR.26, Para. 24.

55 E.g., Portugal, and Norway on behalf of the Nordic States, see Whitney R. Harris World Law Institute, supra note 48, pp. 8 and 9 (with links to full statements).

56 E.g., Belgium, Canada, Estonia and Slovenia, see ibid., pp. 43, 44, 46, and 54 (with links to full statements).

57 On the other hand, at the time of writing, some States were taking regressive steps, including Poland withdrawing from the Istanbul Convention on the basis of its use of gender, see, e.g., BBC, 'Istanbul Convention: Poland to Leave European Treaty on Violence Against Women', available at: https://bbc.in/39ydJaJ. Additionally, discrimination against, and persecution of, LGBTIQ people around the world continues: see, e.g., Human Dignity Trust, available at: www.humandignitytrust.org. 
specific aspects of the ILC's Draft Articles in their submissions during the consultation period. Specifically, there were calls for expanding the persecutory grounds, and suggestions that the definitions of two of the gender-based crimes listed in the crimes against humanity provision, "sexual violence" and "forced pregnancy", need further analysis and possible amendment.

In relation to persecutory grounds, the ILC Special Rapporteur reported that twenty-one UN Special Rapporteurs and an independent expert urged that the grounds for persecution

be expanded and updated so as to include ... grounds of language, social origin, age, disability, health, sexual orientation, gender identity, sex characteristics and indigenous, refugee, statelessness or migratory status. ${ }^{58}$

This viewpoint was shared by some civil society organizations, which referred to numerous resolutions, decisions and declarations by UN and regional human rights and other bodies over the past twenty years recognizing discrimination on the basis of disability, Indigenous status, age, social origin, language and migrant and refugee status. ${ }^{59}$

Ultimately, however, the Special Rapporteur, and subsequently the ILC, declined to add any further grounds to the persecution definition on the basis that the Draft Articles included the catch-all phrase "or other grounds". In the Special Rapporteur's view, this phrase "embraces other and evolving grounds on which persecution may be found". ${ }^{60}$ The counterargument is that the catch-all phrase is not as open ended as indicated, as these "other grounds" must meet the high threshold of "universally recognized as impermissible under international law" ${ }^{61}$ The Special Rapporteur indicated that

the Commission may wish to consider adjusting the commentary so as to provide a fuller account of what is meant by "other grounds that are universally recognized as impermissible under international law", taking into consideration the comments received. ${ }^{62}$

However, the commentary on the list of persecutory grounds simply notes that other grounds were suggested and that the Draft Article "allows for persecution

58 Murphy, supra note 24, Para. 60.

59 Submission of MADRE, OutRight Action International, The Human Rights and Gender Justice Clinic of the City of New York School of Law, and the Center for Socio-Legal Research at the Universidad de Los Andes to the ILC on 'The Definition of Gender in the Draft Crimes Against Humanity Convention', 1 December 2018, on file with the authors.

60 Murphy, supra note 24, Para. 61.

61 See the critique in W. Schabas, The International Criminal Court: A Commentary on the Rome Statute, 1st ed., Oxford, Oxford University Press, 2010, p. 177, noting that the enlargement of the persecutory grounds seemingly promised by the catch-all phrase "may be purely illusory".

62 Murphy, supra note 24, Para. 61. 
on grounds other than those expressly listed, provided that such grounds 'are universally recognized as impermissible under international law"' 63

The crime of other "sexual violence" also attracted some commentary. Draft Article 3(1)(g), copied verbatim from the Rome Statute, provides for the crimes against humanity of "rape, sexual slavery, enforced prostitution, forced pregnancy, enforced sterilization, or any other form of sexual violence of comparable gravity" (emphasis added). In its statement during the debate on the ILC's second reading in the Sixth Committee, Canada said that it "would view negotiations of a convention as an opportunity to clarify the definition of 'sexual violence' to reflect recent discussions within the international community". ${ }^{64}$ Those "recent discussions" include an expert-led global civil society campaign to provide clarity as to the scope of the term 'sexual violence' and to "[enhance] understanding of the many various forms of sexual violence". ${ }^{65}$ After extensive consultations, including with many survivors of a range of sexual violence in different contexts around the world, the campaign adopted the Civil Society Declaration on Sexual Violence in 2019. ${ }^{66}$ The Declaration does not purport to provide an exhaustive list of all forms of sexual violence, but it does describe a wide range of conduct as qualifying as sexual violence. As Canada indicated, the elaboration of a crimes against humanity treaty could provide an important opportunity to clarify and expand the scope and meaning of sexual violence.

Another gender-related issue raised in the commentary on the ILC Draft Articles relates to the crime against humanity of forced pregnancy. ${ }^{67}$ The ILC copied the definition of this crime from Article 7(2)(f) of the Rome Statute: "[T]he unlawful confinement of a woman forcibly made pregnant, with the intent of affecting the ethnic composition of any population or carrying out other grave violations of international law". The provision ends, as it does in the Rome Statute, with "this definition shall not in any way be interpreted as affecting national laws relating to pregnancy". One civil society commentator critiqued inclusion of this final phrase as unresponsive to international legal developments since 1998, referencing, for example, the fact that the Statute of the Special Court for Sierra Leone and several national laws on crimes against humanity do not include it in their definitions of this crime. ${ }^{68}$ Additionally, Canada, in its 2019 statement to the Sixth Committee, indicated that "the current definition of

63 Int'l Law Comm'n, supra note 23, Para. 38. It does note that “[c]ertain other grounds have been suggested [...], such as persecution in the form of acts targeting children on the basis of age or birth".

64 Canada, 'Statement on International Law Commission and Crimes Against Humanity', 31 October 2019, available at: http://statements.unmeetings.org/media2/23328863/-e-canadastatement.pdf.

65 Call it What it is Campaign, available at: https://4genderjustice.org/the-hague-principles/\#.

66 'Civil Society Declaration on Sexual Violence', available at: https://4genderjustice.org/the-hagueprinciples/\#. The Declaration has two Annexures: 1) Commentary on the principles, indicia and examples; and 2) explanation of the methodology applied in developing the Declaration.

67 Global Justice Center, 'Submission to the International Law Commission: The Need to Integrate a Gender Perspective into the Draft Convention on Crimes Against Humanity', November 2018, available at: https://globaljusticecenter.net/files/GJC.CAHSubmission.11.30.2018.pdf. 
'forced pregnancy' would need to be re-examined to ensure that transgender persons are included within the definition". 69

\section{Conclusion: An Overarching Gender Analysis of the Draft Articles Is Needed}

Following the debate on the ILC's second reading of the Draft Articles, the Sixth Committee merely resolved that it would "include in the provisional agenda of its [next] seventy-fifth session an item entitled 'Crimes against humanity' ... to continue to examine the recommendation of the Commission". ${ }^{70}$ However, many States said they would have preferred the Sixth Committee to have resolved to take concrete steps towards the elaboration of a convention. ${ }^{71}$

It remains to be seen what will happen next. At the time of writing, in light of the global COVID-19 pandemic, it is not certain whether the UN General Assembly and its Sixth Committee will be able to convene in 2020. It is also unclear whether States will be willing and able to prioritize the elaboration of a new treaty in the short to medium term in the face of such an immediate and grave threat.

If and when the Sixth Committee does convene, the authors recommend that it step back and examine the ILC's Draft Articles as a whole to determine whether they are fully gender sensitive and gender informed. One way of doing this is to apply 'gender-based analysis plus'. ${ }^{72}$ This is an overarching analysis that would help to identify whether and how the draft treaty has gendered impacts on, for example, victims and accused. The 'plus' acknowledges that gender-based analysis goes beyond biological sex and socially-constructed gender differences, considering intersecting identity factors such as age, race, ethnicity, religion and mental or physical disability. ${ }^{73}$ The analysis would also extend beyond the definition of crimes against humanity to include a number of the other Draft Articles. It would consider, for example, whether non-discrimination clauses should be added to ensure that investigations and extraditions are undertaken without discrimination on various grounds, including gender, and that victim protection is conducted in a gender-informed manner.

In the authors' view, the ILC made the correct decision to delete the Rome Statute's definition of 'gender' from the Draft Articles. Given the polarized debate on the term 'gender' in Rome, it would be disruptive and unproductive to open the definition to re-negotiation in the context of a new crimes against humanity

69 Canada, supra note 64.

70 UNGA Res. 74/187, 30 December 2019, Para. 3.

71 Forty-three countries expressed this preference. See Statement by Austria (on behalf of 42 other countries), 74th Session of the General Assembly, 6th Committee, under agenda item 79 (20 November 2019), Para. 33.

72 This type of analysis is commonly used in domestic and international policy and legal circles to ensure that policies and laws do not result in negative gendered impacts.

73 Status of Women Canada, 'What Is Gender-Based Analysis Plus?', available at: https://cfcswc.gc.ca/gba-acs/index-en.html. Other intersecting identity factors, such as sexual orientation, gender identity and intersex, non-binary and trans status are included in the gender analysis. 
treaty. That said, it should be noted that, in the context of the Rome Statute, the definition of 'gender' is neither "outdated" nor "obsolete", as it is continually informed by Article 21(3), which requires the ICC to interpret the definition in line with evolving international law. In this way, the drafters of the Rome Statute ensured that the ever-growing understanding of how gender is socially constructed informs the definition. The Draft Articles, in their current form, do not include such a requirement. Perhaps they should, so as to clarify that domestic understandings of crimes against humanity evolve along with international law. ${ }^{74}$

In conclusion, the debate on the term 'gender' in the ILC's Draft Articles has revealed an impetus in some parts of the international community towards acceptance of a wider and deeper understanding of the socially-constructed origins and aspects of gender, as well as continued opposition to this understanding by a small minority of States. The ILC process has also highlighted other potential areas needing consideration, such as the list of persecutory grounds and the definition of sexual violence, which would benefit from further analysis. Indeed, the discussion to date indicates that the Draft Articles are ripe for further genderfocused analysis. gations under international law, including international human rights law and non-discrimination norms prohibiting persecution of, for example, women and LGBTIQ individuals. 